\title{
ON THE USE OF TELEPHONE POLES FOR THE OBSERVATION OF AREAL SNOW-DEPTH DISTRIBUTION
}

\author{
By Katsuhiro Kikuchi \\ (Department of Geophysics, Faculty of Science, Hokkaido University, Sapporo, Japan)
}

\begin{abstract}
For the observation of areal snow-depth distribution over a wide area, such as the Ishikari Plain in Hokkaido, Japan, existing telephone poles were used in place of the snow scales. Telephone pole number plates (telephone poles in Japan have number plates) were photographed by a $35 \mathrm{~mm}$ camera with zoom lens ranging from $80 \mathrm{~mm}$ to $200 \mathrm{~mm}$ through the window of the observation vehicle. The snow depth was calculated by the ratios of the length of the number plates to the distance between the lower edge of the number plates and the snow surface. Since measurements by direct sounding using a rod as compared with the values by the above method showed a good coincidence with an accuracy of $\pm 10 \mathrm{~cm}$, it was considered satisfactory for snow depth observation over a wide area.
\end{abstract}

RÉsumé. Sur l'utilisation des poteaux de téléphone pour l'observation de l'épaisseur de la neige dans une surfaco. Pour l'observation de la distribution de l'épaisseur de la neige dans un secteur de grande étendue tel que la plaine d'Ishikari dans l'île d'Hokkaido au Japon, on a utilisé des poteaux téléphoniques existants comme perches à neige. Les plaques de numérotation des poteaux téléphoniques (les poteaux téléphoniques au Japon ont des plaques de numérotation) ont été photographiés avec une caméra de $35 \mathrm{~mm}$ avec un objectif zoom allant de 80 à $200 \mathrm{~mm}$, à travers la fenêtre d'un véhicule d'observation. L'épaisseur de la neige a été calculée par le rapport entre la longueur de la plaque de numérotation et la distance entre la bord de cette plaque et la surface de la neige. Des mesures directes à la sonde à neige comparées aux valeurs obtenues par la méthode décrite ci-dessus, ont montré une bonne coïncidence avec une précision de $\pm 10 \mathrm{~cm}$, qui est considérée comme satisfaisante pour l'observation de la profondeur de la neige dans un secteur étendu.

Zusammenfassung. Über die Benutzung von Telefonmasten zur flachenhaften Beobachtung der Schneetiefenverteilung. Zur Beobachtung der Schneetiefenverteilung über einem grossen Gebiet - wie etwa der Ishikari-Hochebene auf Hokkaido, Japan - wurden Telefonmasten anstelle von Schneepegeln verwendet. Die in Japan üblichen Nummernplatten der Telefonmasten wurden mit einer $35-\mathrm{mm}$-Kamera mit einem Zoomobjektiv von $80 \mathrm{~mm}$ bis $200 \mathrm{~mm}$ durch das Fenster des Beobachtungswagens photographiert. Die Schneetiefe wurde aus dem Verhältnis der Länge der Nummernplatten zum Abstand zwischen Unterkante der Nummernplatte und Schneeoberfläche berechnet. Da die Messungen durch unmittelbare Sondierung mit Messlatten im Vergleich zu den Werten nach der oben beschriebenen Methode eine gute Übereinstimmung innerhalb von $\pm \mathrm{IO} \mathrm{cm}$ zeigen, wurde diese Methode zur Bestimmung der Schneetiefen über grosse Gebiete als zufriedenstellend angesehen.

\section{INTRODUCTION}

The author's purpose was to conduct a detailed investigation on the characteristic snow-depth distribution in the Ishikari Plain, Hokkaido, Japan (Higuchi, 1962; Lee and others, 1972) in association with the cloud distribution by radar echoes over the area (Kikuchi, 1967; Harimaya, 1970). Inadequacy of basic data forced him to develop a simple and efficient technique of measuring snow depth in the area, covering approximately $20 \mathrm{~km} \times 40 \mathrm{~km}$. This paper describes the usefulness of telephone poles in place of snow scales for snow depth observations over a wide area.

\section{Observation techniques}

Although snow depth is usually measured by snow scales, it is difficult to set up and maintain a hundred or more snow scales in a sizable area. But telephone poles are strung along major roads in the plain, and each pole has a number plate with an identification number on it facing the road as shown in Figure $\mathbf{~}$. If the length of the number plate itself and the height of the number plate on each pole from the ground are known by some means, the snow depth can be obtained by the calculation of the ratio of the length of the number plate to the height of the number plate from the snow surface. To obtain the ratio, telephone poles were photographed with a $35 \mathrm{~mm}$ camera with zoom lens ranging from $80 \mathrm{~mm}$ to $200 \mathrm{~mm}$. The photographs were enlarged generally to a quarter-plate size and the length of the number plate and the distance between the lower edge of the number plate and the snow surface was measured by a scale. A total of 102 telephone poles was selected as the observation poles in the area and the height of the lower edge of the number plate on each was measured before the winter season. Then during the winter they were photographed through the window of the observation vehicle. It required $\mathrm{r} .5 \mathrm{~d}$ to cover the entire circuit connecting poles amounting to a distance of approximately $350 \mathrm{~km}$. Observations were made one or two times per month during November through to March. 

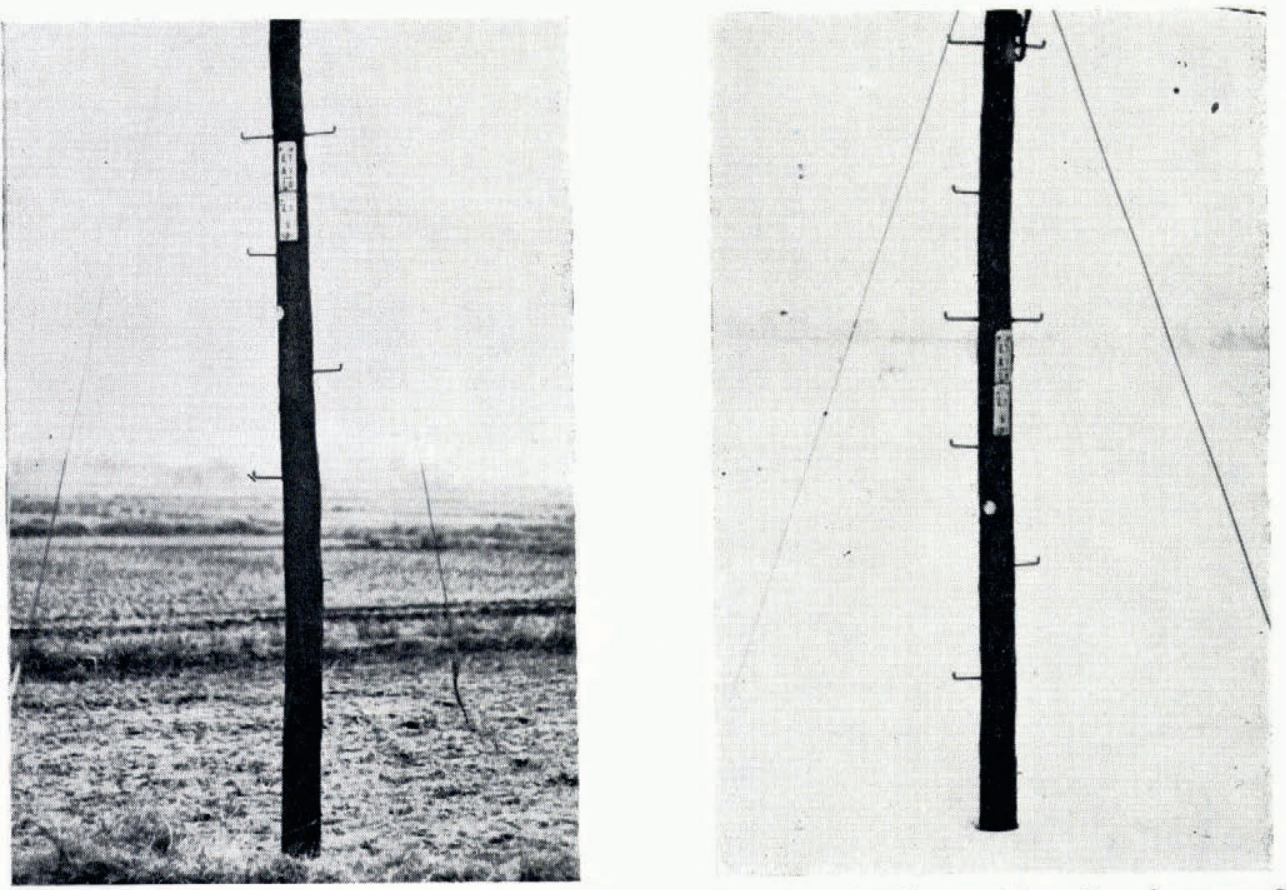

Fig. 1. A typical example of a telephone pole used as a snow scale. Observation point No. 39. (a) 20 November 197o. Snow depth $=0 \mathrm{~cm} .(b)$ IO March 1971 . Snow depth $=108 \mathrm{~cm}$. The length of the number plate on the telephone pole in (a) and $(b)$ is the same.

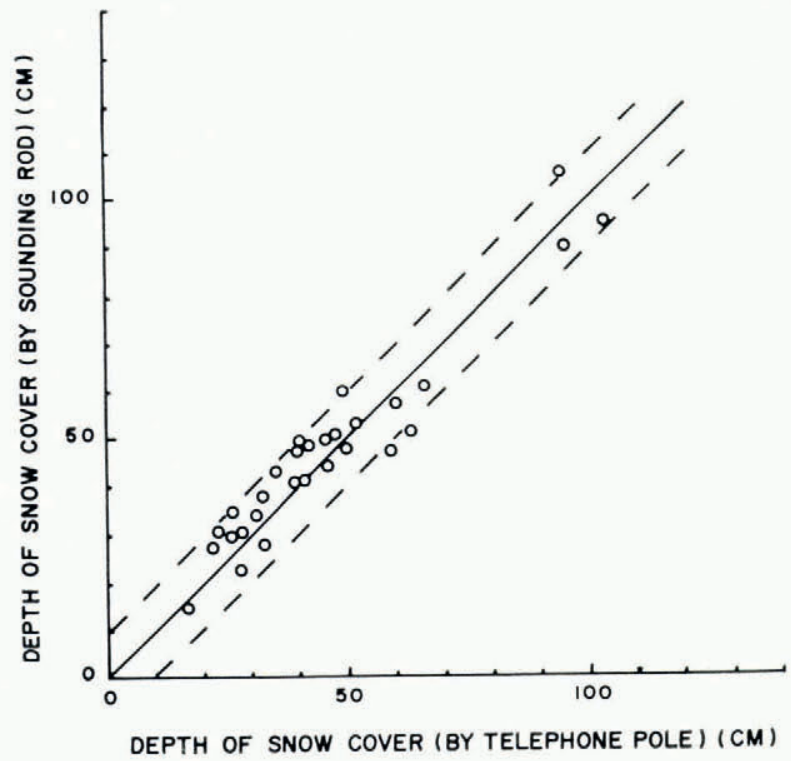

Fig. 2. The relation between the value of the snow depth obtained by calculation using telephone poles and that obtained by direct measurement using a sounding rod. 


\section{Results}

Figure 2 shows the relation between the snow depths obtained by telephone poles and by sounding rod. Dashed lines show the difference of $\pm 10 \mathrm{~cm}$. As is seen, the values obtained from the telephone poles coincide relatively well within an error of $\pm 10 \mathrm{~cm}$. Since the maximum snow depth in this area is $2 \mathrm{~m}$ or so, it was found satisfactory to use the telephone poles for snow-depth observations.

An example of the snow-depth distribution obtained by this technique is shown in Figure 3. A band type of the deepest snow depth extending from west-north-west to east-south-east in the plain was clearly recognized. The position of the band was approximately io $\mathrm{km}$ north-east of Sapporo.

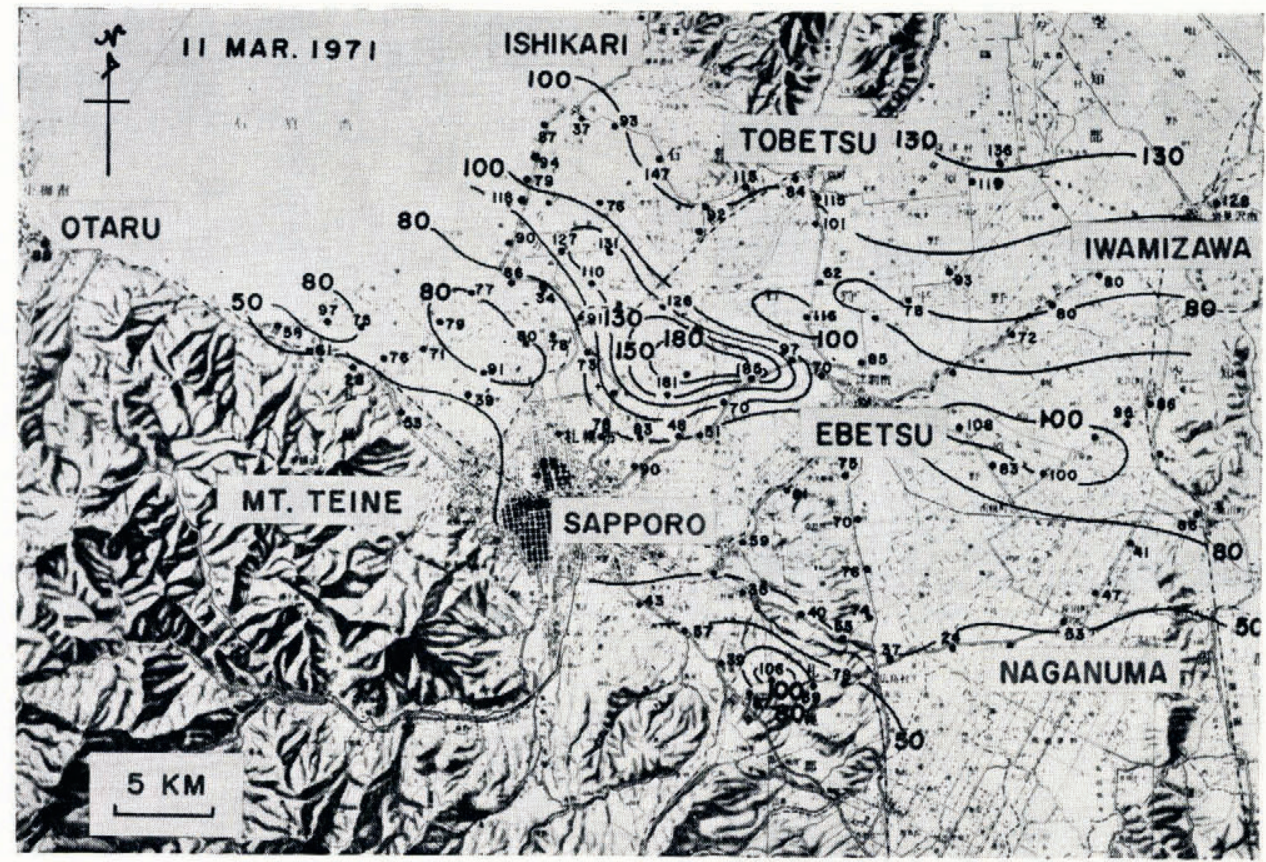

Fig. 3. An example of the snow-depth distribution on the Ishikari plain, Hokkaido, on II March I97I. (Depths marked in centimetres.)

\section{Conclusions}

For the observation of the snow-depth distribution over a wide area, such as the Ishikari Plain in Hokkaido, existing telephone poles were used in place of snow scales. Since measurements by direct sounding using a rod as compared with the values by the above method showed a good coincidence with an accuracy of $\pm 10 \mathrm{~cm}$, it was considered that it was satisfactory to use the telephone poles for snow depth observations over a wide area. Furthermore, the distribution of telephone poles were adequate for our requirements. If a larger number of telephone poles are selected in suitable positions covering the area, it would be possible to grasp the true characteristics of the snow-depth distribution over the plain. This method can be applied for the measurement of new fallen snow after each snowfall, if two or more observation vehicles are used.

\section{Acknowledgements}

The author wishes to express his thanks to Professor C. Magono and to T. Endō, T. Harimaya, M. Kajikawa and T. Ishikawa in his laboratory, for their cooperation in the observation.

The expense of this study was defrayed by a Special Fund for Scientific Researches of the Government of Hokkaido. 


\section{REFERENCES}

Harimaya, T. 1970. Hokkaidō nishikaigan oki de hassei suru shōteikiatsu ni tsuite [On the small-scale cyclone formed on the Japan Sea to the west of Hokkaido island]. Hokkaidō Daigaku Chikyū-Butsurigaku Kenkyū Hōkoku : Geophysical Bulletin of Hokkaido University, No. 23, p. 73-82.

Higuchi, K. 1962. On the characteristics of snow clouds. Fournal of the Meteorological Society of Japan, Vol. 40, No. 4 , p. I93-20I.

Kikuchi, K. I967. On the characteristic distribution of snow crystals during a snowfall on the Ishikari plain, Hokkaido. Fournal of the Faculty of Science, Hokkaido University, Ser. 7, Vol. 3, No. 1, p. 37-47.

Lee, C. W., and others. 1972. Ishikari-heiya no kōsetsu no suihei bunpu. I. Nairikubu no kōsetsu to kaze [The horizontal distribution of snowfall on the Ishikari plain, Hokkaido. I. The snowfall and the wind in the land]. [By] C. W. Lee, K. Kikuchi [and] C. Magono. Hokkaidō Daigaku Chikyū-Butsurigaku Kenkyū Hōkoku: Geophysical Bulletin of Hokkaido University, No. 27, p. 13-24. 